\title{
Microstructure Control of Secondary A 231 Cast Alloy Used in Automotive Industry
}

Lenka Hurtalová, Eva Tillová, Mária Chalupová, Juraj Belan, Alan Vaško

Faculty of Mechanical Engineering, University of Žilina, Univerzitná 8215/1, 01026 Žilina. Slovak Republic. E-mail: lenka.hurtalova@fstroj.uniza.sk, eva.tillova@fstroj.uniza.sk, maria.chalupova@fstroj.uniza.sk, juraj.belan@fstroj.uniza.sk, alan.vasko@fstroj.uniza.sk

The application of Al-Si alloy castings has gradually increased in many mechanical components in the last years, especially for cars and rail vehicles, thanks to the great potential of these materials as replacements for ferrous alloys. Controlling the microstructure of secondary aluminium cast alloy (Al-scrap and workable Al-garbage) is very important, because these alloy containing more of additions elements, that forming various intermetallic phases in the structure. The mechanical properties are strongly depending on the morphologies, type and distribution of the structural parameters. Microstructure control was realized with combination of different analytical techniques (light microscopy, scanning electron microscopy (SEM) upon deep etching and energy dispersive Xray analysis - EDX).

Keywords: Al-Si cast alloy, mechanical properties, SEM, deep etching, X-ray analysis

\section{Acknowledgement}

This work has been supported by Scientific Grant Agency of Ministry of Education of Slovak Republic and Slovak Academy of Sciences, No1/0841/11 and project EU ITMS 26220220154.

\section{References}

[1] DIN EN $1706: 06 / 98$. Aluminum die casting alloys

[2] MILLER, W. S., et al. (2000). Recent development in aluminium alloys for the automotive industry. In: Materials Science and Engineering, Vol. A280, pp. 37-49.

[3] WANG, Q. G., APELIAN, D., LADOS, D. A. (2001). Fatigue Behavior of A356/357 Aluminum Cast Alloys part II. Efect of Microstructural Constituents. In: Journal of Light Metals, Vol. 1, pp. 85-97.

[4] MATVIJA, M., et al. (2012). The effect of ECAP and subsequent post-ecap annealing on the microstructure and mechanical properties of AlSi7Mg0.3 alloy. In: Acta Metallurgica Slovaca, Vol. 18, No. 1, pp. 4-12.

[5] SENČÁKOVÁ, L., VIRČÍKOVÁ, E. (2007). Life cycle assessment of primary aluminium production. In: Acta Metallurgica Slovaca, Vol. 13, No. 3, pp. 412-419.

[6] DAS, K. S. (2006). Designing Aluminum Alloys for a Recycling Friendly World. In: Materials Science Forum, Vol. 519-521, pp. 1239-1244.

[7] CUI, J., ROVEN, H. R. (2010). Recycling of automotive aluminum. In: Transactions nonferous metal Society China, Vol. 20, pp. 2057-2063.

[8] TAVITAS-MEDRANO, J. F., et al. (2009). Precipitation - hardening in cast Al-Si-Cu-Mg alloys. In: Journals of Materials Science, Vol. 45, No. 3, pp. 641-651.

[9] WARMUZEK, M. (2004). Aluminium/Silicon Alloys: Atlas of Microfractographs. Introduction to Aluminium Silicon Casting Alloys.

[10] MOUSTAFA, M. A., et al. (2003). Effect of solution heat treatment and additives on the microstructure of Al-Si (A413.1) automotive alloys. In: Journal of Material Science, Vol. 38, No. 22, pp. 4507-4522.

[11] SAMUEL, A. M., SAMUEL, F. H., DOTY, W. H. (1996). Observations on the formation of 13-AlFeSi phase in 319 type Al-Si alloys. In: Journal of Material Science, Vol. 31, pp. 5529-5539.

[12] MICHNA, Š., LUKÁČ, I., NAPRSTKOVÁ, N. (2009). AA4032 alloy’s heat treatment and its influence into substructure. In: Manufacturing technology, Vol. IX, pp. 6-11.

[13] MICHALCOVÁ, A., VOJTĚCH, D. (2012). Structure of rapidly solidified aluminium alloys. In: Manufacturing technology, Vol. 12, No. 13, pp. 166-169.

[14] NÁPRSTKOVÁ, N., KUSMIERCZAK, S., CAIS, J. (2013). Modification of AlSi7Mg0.3 alloy by strontium. In: Manufacturing Technology, Vol. 13, Issue 3, pp. 373-380. 
[15] SUN, Y., PANG, S-P., LIU, X-R., YANG, Z-R., SUN, G-X. (2011). Nucleation and growth of eutectic cell in hypoeutectic Al-Si alloy. In: Transactions nonferous metal Society China, Vol. 21, pp. 2186-2191.

[16] HURTAlOVÁ, L., TILlOVÁ, E. (2013). Elimination of the negative effect of Fe-rich intermetallic phases in secondary (recycled) aluminium cast alloy. In: Manufacturing technology, Vol. 13, N. 1, pp. $44-50$.

[17] DOBRZAŃSKI, L. A., et al. (2007). Microstructure and mechanical properties of AC AlSi9CuX alloys. In: Journal of Achievements in Materials and Manufacturing Engineering, Vol. 24, No. 2, pp. 51-54.

[18] HONZÁTKO, R., MICHNA, Š., CAIS, J. (2013). The Influence of Porosity on Mechanical Properties of Casts Produced from Al - Si Alloys. In: Manufacturing Technology, Vol. 13, No. 3, pp. 319-324.

[19] TILlOVÁ, E., CHALUPOVÁ, M. (2009). Structural analysis (Štruktúrna analýza), Edis Žilina (in Slovak).

[20] WANG, S-R., et al. (2012). Growth mechanism of primary silicon in cast hypoeutectic Al-Si alloys. In: Transactions nonferous metal Society China, Vol. 22, pp. 1264-1269.

[21] SEIFEDDINE, S. (2007). The influence of Fe on the microstructure and mechanical properties of cast Al-Si alloys. In: Literature review - Vilmer project. Jönköping University, Sweden

[22] TAYLOR J. A. (2004). The effect of iron in Al-Si casting alloys. In: 35th Australian Foundry Institute National Conference, pp. 148-157, Adelaide, South Australia

[23] CACERES, C. H.; SVENSON, I. L. \& TAYLOR, J. A. (2003). Strenght-ductility Behaviour of Al-Si-Cu-Mg Casting Alloys in T6 temper. International Journal of Cast Metals Research, No. 15, pp. 531-543.

[24] MA, Z., et al. (2008). A study of tensile properties in Al-Si-Cu and Al-Si-Mg alloys: Effect of $\beta$-iron intermetallics and porosity. In: Materials Science and Engineering A, Vol. 490, pp. 36-51.

[25] KIM, H. Y., PARK, T. Y., HAN, S. W., MO, L. H. (2006). Effects of Mn on the crystal structure of $\alpha-\mathrm{Al}(\mathrm{Mn}, \mathrm{Fe}) \mathrm{Si}$ particles in A356 alloys. In: Journal of Crystal Growth, Vol. 291, No. 1, pp. 207-211.

[26] BOLIBRUCHOVÁ, D., RICHTÁRECH, L. (2013). Effect of adding iron to the AlSi7Mg0.3 (EN AC 42100 , A356) alloy. In: Manufacturing Technology, Vol. 13, No. 3, pp. 276-281.

[27] BOBOESCU, R., SPOREA, I., BORDEASU, I., TOKAR, A., BUJOR, V. (2008). The usage of type siliuminiu alloys with magnesium for casting a very large used pieces. In: Acta technical corviniensis - bulletin of engineering, Vol. 1, pp. 41-44. Hunedoara, Romania. 